Historia i Polityka

Półrocznik poświęcony myśli politycznej i stosunkom międzynarodowym

$\mathrm{Nr} 10(17) / 2013131-135$

DOI: http://dx.doi.org/10.12775/HiP.2013.016

Joanna Rak (Uniwersytet Mikołaja Kopernika w Toruniu)

\title{
Agata W. Ziętek \\ Bezpieczeństwo kulturowe w Europie \\ Wydawnictwo Uniwersytetu Marii Curie-Skłodowskiej \\ Lublin 2013, ss. 323
}

$\mathbf{L}$

uki w polskojęzycznej literaturze z zakresu bezpieczeństwa kulturowego nie wypełniła niestety monografia autorstwa Agaty W. Ziętek pt. „Bezpieczeństwo kulturowe w Europie”. Po pierwsze trudno jednoznacznie określić co jest przedmiotem analiz autorki: bezpieczeństwo kulturowe, społeczne, międzynarodowe, narodowe, wewnętrzne, zewnętrzne, społeczne poczucie bezpieczeństwa kulturowego, kultura w bezpieczeństwie, międzynarodowe stosunki kulturowe, polityka bezpieczeństwa kulturowego, polityka czy kultura w ogóle, a może wszystko po trochu. Akcydentalne i swobodne stosowanie wybranych pojęć, nieraz w roli synonimów - wbrew ich zgoła różnym znaczeniom - powoduje zniknięcie z pola widzenia czytelnika właściwego przedmiotu badań. Poza tym podczas lektury nasuwa się wiele zastrzeżeń dotyczących metodologii, które zostały uwzględnione w niniejszej recenzji.

Znaczącą słabość badania zaprezentowanego na łamach publikacji A. W. Ziętek stanowi fakt, iż autorka nie zakreśliła pola badawczego i jego granic: merytorycznych i czasowo-przestrzennych. Rezygnacja z tego trudnego, lecz niesłychanie ważnego kroku w postępowaniu badawczym, brak precyzyjnego określenia istoty oraz zakresu zjawisk, które będą objęte analizą obniżyły wartość naukową oraz poznawczą monografii.

Agata W. Ziętek wskazała we wstępie, iż: „Celem książki jest analiza dynamiki bezpieczeństwa w odniesieniu do niewojskowego wymiaru bezpieczeństwa w Europie, która jest traktowana szerzej niż tylko obszar Unii Europejskiej, chociaż państwa UE są ważnym przedmiotem analizy ze względu na aktywność normatywną i praktykę działań politycznych, zarówno podmiotów państwowych, jak i niepaństwowych...”. Warto zauważyć, iż już pierwszy z zadeklarowanych celów nie dotyczy stricte tytułowego bezpieczeństwa kulturowego.

1 A. W. Ziętek, Bezpieczeństwo kulturowe w Europie, Lublin 2013, s. 11. 
Następnie autorka dodała: „Celem było wykazanie, że zagrożenia bezpieczeństwa kulturowego mają charakter dynamiczny, zmieniają się w czasie i kontekście. Występują na poziomie środowiska międzynarodowego i na poziomie państwa, chociaż ich granice mają charakter transwersalny. Są swego rodzaju kontinuum bezpieczeństwa wewnętrznego i zewnętrznego..."2. Poza tym, że są to dość banalne konkluzje, trzeba dostrzec skupienie na zagrożeniach, a nie bezpieczeństwie ${ }^{3}$. Ostatni z wymienionych przez autorkę celów, został z kolei nakreślony następująco: „Celem było również wskazanie, że specyfika i istota bezpieczeństwa kulturowego polegają na subiektywnym przekonaniu o występowaniu lub niewystępowaniu zagrożeń, co nie jest jednoznaczne z obiektywnym istnieniem" ${ }^{4}$. Ostatecznie zaciemnia on cel badania zorientowanego na identyfikację treści i zakresu pojęcia bezpieczeństwa kulturowego - czy jak wynika z kontekstu zdania - społecznego poczucia bezpieczeństwa kulturowego ${ }^{5}$. Wielu spośród wskazanych błędów można by uniknąć poprzez adaptację na grunt naukowej refleksji o bezpieczeństwie teorii względnej deprywacji ${ }^{6}$, a także sfor-

2 Ibidem.

3 Por. M. Księżopolski, Bezpieczeństwo społeczne i jego zagrożenia, [w:] Polityka społeczna w okresie przemian, red. A. Piekara, J. Supińska, Warszawa 1985, s. 18-34.

A. W. Ziętek, op. cit., s. 11.

Zob. w tym kontekście np. E. Rose, G. Willoughby, Culture Profiles and Emphases, „American Journal of Sociology” 1958, vol. 63, nr 5, s. 476-490; B. P. Dohrenwend, R. J. Smith, Toward a Theory of Acculturation, "Southwestern Journal of Anthropology" 1962, vol. 18, nr 1, s. 30-39; A. F. C. Wallace, Revitalization Movements, „American Anthropologist" 1956, vol. 58, nr 2, s. 264-281; G. Guariglia, Prophetismus und Heilserwartungsbewegungen bei den niedrigen Kulturen, "Numen” 1958, vol. 5, nr 3, s. 180-198.

6 Zob. np. B. Barber, Acculturation and mes- mułowanie od podstaw założeń metodologicznych i teoretycznych.

Niestety Agata W. Ziętek nie sformułowała na potrzeby swojej pracy problemów badawczych ani kategorii teoretycznej. Niemniej zaprezentowała hipotezy, które warto przywołać: 1. „bezpieczeństwo kulturowe jest częścią bezpieczeństwa ogólnego państw, ale niekoniecznie wszystkich jego mieszkańców"; treść pierwszej hipotezy jest tak oczywista, że dziwi manifestacja potrzeby jej weryfikacji; 2. „brak zagrożeń dla państwa nie oznacza, że takich zagrożeń nie odczuwają jego mieszkańcy"; drugiej tak samo, przy czym odbija się w niej brak namysłu nad przedmiotem badania; 3. „osią bezpieczeństwa kulturowego i wartością chroniona jest tożsamość. Możliwość uzewnętrznienia swojej tożsamości, gwarancja wolności form wyrazu kulturowego przez tradycję, język, religię, uwolnienie od ograniczeń, jednocześnie zachowanie swojej specyfiki w zmiennych warunkach będą wpływały na percepcję bezpieczeństwa kulturowego"; dyspozycja zweryfikowania wskazanego wpływu jest w tym przypadku wątpliwa, zwłaszcza w obliczu ewidentnego braku narzędzi; 4. „zagrożenia bezpieczeństwa kulturowego są konsekwencją negatywnych zmian w środowisku kulturowym państw, powstających na poziomie środowiska międzynarodowego i na poziomie państwa, i definiowanych w procesie sekurytyzacji”; kolejna hipoteza jest równie banalna jak pierwsza i druga - zauważenie znaczenia procesów globalizacji dla zjawisk społecznych, choć jest istotne, to samo w sobie nie stanowi odkrycia ${ }^{7}$. Zastana-

sianic movements, "American Sociologist Review” 1941, vol. 6, nr 6, s. 663-669.

Zob. np. R. Bäcker, Nietradycyjna teoria polityki, Toruń 2011, s. 85-90; S. Näsström, What Globalization Overshadows, „Political Theory” 2003, vol. 31, nr 6, 808-834; T. Hellwig, Globalization and 
wiające jest także przyznanie procesowi sekurytyzacji szczególnego znaczenia w sferze identyfikacji zagrożeń bezpieczeństwa kulturowego. Brakuje tutaj porządnego uzasadnienia zawierającego argumenty za obranym stanowiskiem; 5. „kultura jest zmienną niezależną i zależną, a bezpieczeństwo zmienną zależną. Percepcja bezpieczeństwa zmienia się w czasie, w zależności od kontekstu i od podmiotu oceniającego. Kultura może wpływać na postrzeganie

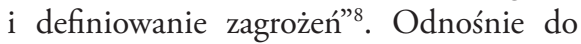
ostatniej hipotezy znajdują zastosowanie sformułowane wcześniej zastrzeżenia. Jest banalna - np. nie wnosi niczego konstatacja, iż nie ma jednego raz danego, niezależnego od miejsca i czasu stanu bezpieczeństwa. To oczywiste. Co więcej, autorka po raz kolejny wspomniała również o kwestii wpływu, pomimo że nie pokazała w jaki sposób chciałaby go zidentyfikować. Trzeba także nadmienić, iż nieprecyzyjne po-

Perceptions of Policy Maker Competence: Evidence from France, „Political Research Quarterly” 2007, vol. 60, nr 1, 146-158; E. O. K. Prempeh, Anti-Globalization Forces, the Politics of Resistance, and Africa: Promises and Perils, „Journal of Black Studies” 2004, vol. 34, nr 4, 580-598; M. L. Wax, How Culture Misdirects Multiculturalism, „Anthropology \& Education Quarterly” 1993, vol 24, nr 2, 99-115; M. J. Herskovits, On the Values in Culture, „The Scientific Monthly” 1942, vol. 54, nr 6, s. 559; Z. Nowakowski, Wplyw globalizacji na bezpieczeństwo narodowe. Wyzwania $i$ zagrożenia, "Studia Bezpieczeństwa Narodowego” 2011, nr 2, s. 225-238; M. S. Edwards, Public Opinion regarding Economic and Cultural Globalization: Evidence from a Cross-National Survey, "Review of International Political Economy” 2006, vol. 13, nr 4, 587-608; D. Parisi, F. Cecconi, F. Natale, Cultural Change in Spatial Environments: The Role of Cultural Assimilation and Internal Changes in Cultures, „The Journal of Conflict Resolution” 2003, vol. 47, nr 2, 163-179. Zob. także nt. postaw: P. M. Sniderman, D. B. Grob, Innovations in Experimental Design in Attitude Surveys, "Annual Review of Sociology” 1996, vol. 22, s. 377-399.

8 Zob. hipotezy: A. W. Ziętek, op. cit., s. 12. służyła się pojęciami, za pomocą, których sformułowała hipotezy. Wymagają one ponownego rozważenia. Nie powinny także powstać - jak tutaj - ad hoc, lecz stanowić przypuszczalne odpowiedzi na problemy badawcze - główny i szczegółowe, ewentualnie także poboczne, w przypadku ambicji zbadania przedmiotu leżącego poza zakresem pola badawczego.

Wątpliwości wzbudza także dobór metod badawczych, tym bardziej, że autorka go nie uzasadniła: „Badając zagrożenia kulturowe i podejmowane działania, zastosowano metody - czynnikową oraz analizy zawartości dokumentów. Dokonano zatem przeglądu konwencji i deklaracji Organizacji Narodów Zjednoczonych, Rady Europy, Unii Europejskiej, na poziomie wewnętrznym - ustaw i zapisów konstytucyjnych powiązanych z bezpieczeństwem kulturowym. Przeanalizowano strategie polityczne ze szczególnym uwzględnieniem Polski" . Wynikanie nie jest jednak wcale tak oczywiste w tym przypadku, jak wskazała A. W. Ziętek. Stwierdziła tylko, iż: „Umożliwiło to ukazanie znaczenia regulacji z punktu widzenia bezpieczeństwa kulturowego, tym samym wskazano, że bezpieczeństwo kulturowe jest nie tylko przedmiotem akademickich dociekań, ale również obszarem debaty politycznej. Wykorzystano także dane statystyczne, które poddano analizie, aby zweryfikować postawione cele badawcze. Zastosowano podejście dedukcyjne, teoretyczno-empiryczne, od ogólnych rozważań teoretyczno-pojęciowych do analizy konkretnych przypadków zagrożeń i działań”10. Zasugerowała zatem użycie trzech metod badawczych, pomimo że wymieniła dwie. Nie wyjaśniła także w jaki sposób zamierzała je zastosować. Uczciwie nie wskazała

\footnotetext{
9 Zob. Ibidem, s. 13.

10 Zob. nt. metodologii w pracy: ibidem.
} 
też żadnej techniki ani narzędzia (dziwi to zwłaszcza w obliczu zamanifestowanych ambicji zbadania tak newralgicznej kwestii, jaką jest wpływ), ponieważ nie wykorzystała ich w toku pracy, stąd trudno mówić w tym przypadku o badaniu. Warto również zauważyć, że autorka wielokrotnie użyła słów bez uprzedniego namysłu nad ich znaczeniem. Dowolnie, w zależności od potrzeby nadawała sens pojęciom, np. „teorii”, czerpiąc z języka potocznego, konfrontując „teorię” z „empirią” itd. ${ }^{11}$. Posługiwała się nimi, nie definiując ich (np. „środowisko kulturowe”). Spowodowało to utratę waloru precyzji artykulacji.

Należy także wskazać, iż polonocentryzm znajdujący ujście zarówno w przywołanym fragmencie dotyczącym metod badawczych, jak i w wywodzie zamieszczonym na łamach kolejnych rozdziałów jest nieuzasadniony. Przykładowo autorka omawiając „wymiar polityczny bezpieczeństwa kulturowego w Europie” wyróżniła bezpieczeństwo kulturowe w: debacie w Organizacji Narodów Zjednoczonych, procesie Organizacji Bezpieczeństwa i Współpracy Europejskiej, Radzie Europy, Unii Europejskiej i Polsce. Tym samym wykazała się emocjonalnym, a więc nienaukowym stosunkiem do Polski ${ }^{12}$. Trudno także znaleźć argumenty za potrzebą przypisania Polsce szczególnej roli w zakresie bezpieczeństwa kulturowego w Europie, tym bardziej, że A. W. Ziętek nie wyjaśniła tego zabiegu ani nie dowiodła jego zasadności.

Autorka, choć wykazała się doskonałą znajomością światowej literatury przed-

11 Zob. B. Krauz-Mozer, Teorie polityki. Założenia metodologiczne, Warszawa 2007, s. 54.

12 Zob. A. Furdal, Jak być Polakiem w Unii Europejskiej, Wrocław 2003, s. 13-16. Por. także uwagi na temat takiego podejścia: A. Wielomski, Myśl polityczna Reformacji i Kontrreformacji. Tom I, Rewolucja protestancka, Radzymin 2013, s. 9. miotu, nie skorzystała z jej dyspozycji. Wielokrotnie bowiem odbiorca ma wrażenie, że kolejność cytowanych pozycji bibliograficznych jest przypadkowa. Następujące po sobie cytaty czy omówienia fragmentów publikacji niczego nie wnoszą do rozważań zaprezentowanych w publikacji. Brakuje przede wszystkim uzasadnień ich przywołania, omówień, interpretacji, krytycznego oglądu oraz konkluzji pozwalających odpowiedzieć na pytanie - co dane stanowisko wnosi do treści pracy.

$\mathrm{Na}$ koniec warto wspomnieć, że książka składa się z pięciu rozdziałów zatytułowanych kolejno: „Bezpieczeństwo kulturowe w stosunkach międzynarodowych", "Zagrożenia bezpieczeństwa kulturowego w Europie”, „Podstawy normatywne bezpieczeństwa kulturowego w Europie”, „Działania na rzecz bezpieczeństwa kulturowego w Europie”, „Działania podmiotów pozarządowych na rzecz bezpieczeństwa kulturowego w Europie". Pierwszy zawiera charakterystykę wymiarów: ontologicznego, epistemologicznego, politycznego bezpieczeństwa kulturowego. Nie jest on wolny od zasygnalizowanych wcześniej błędów. W następnym znajduje się omówienie zagrożeń bezpieczeństwa kulturowego na poziomie środowiska międzynarodowego i państwa. Taki podział i próby typologizowania w łonie wskazanych kategorii wzbudzają wątpliwości, co do aktualności i są świadectwem nieuwzględnienia niuansów właściwych erze informatycznej. Rozdział trzeci to deskrypcja regulacji w zakresie: zachowania materialnej substancji kulturowo-cywilizacyjnej i zróżnicowania w obszarze wartości niematerialnych, a także ochrony „grup szczególnego ryzyka” (mniejszości kulturowych, etnicznych, ludów tubylczych)". Przedostatni rozdział został poświęcony na opis działań na poziomie 
środowiska międzynarodowego, działań państw na rzecz bezpieczeństwa kulturowego, desekurytyzacji jako strategii działania państw. Ostatni natomiast zawiera przedstawienie i ocenę podmiotów pozarządowych działających w obszarze kultury. W jego ramach ponownie, w sposób nieuzasadniony autorka zamanifestowała nienaukową postawę polonocentryczną, wyodrębniając podrozdział pt. „Działania podmiotów pozarządowych w Polsce". Deskryptywny charakter wywodu oraz wskazane niedostatki sprawiają, że ta monografia to raczej podręcznik z zakresu międzynarodowych stosunków kultu- rowych, aniżeli praca badawcza na temat bezpieczeństwa kulturowego.

Szeregu nieścisłości mogła A. W. Ziętek uniknąć, gdyby przed przystąpieniem do pisania książki dokładnie zaprojektowała badanie, które zamierzała przeprowadzić. Trzeba jednak przyznać, że zasadniczym walorem publikacji jest dołączona do niej bibliografia. Po dokonaniu odpowiedniej selekcji, może bowiem okazać się ona cenną wskazówką dla osób zajmujących się bezpieczeństwem kulturowym. Nie poleca się tej książki jednak odbiorcy poszukującemu wzorcowego raportu z badania dotyczącego bezpieczeństwa kulturowego. 